\title{
African Peacekeepers in Africa
}

The Role of United States Assistance and Training

Emmanuel, Nikolas G.

Published in:

African Security Review

DOI:

10.1080/10246029.2014.993668

Publication date:

2015

Document version

Early version, also known as pre-print

Citation for published version (APA):

Emmanuel, N. G. (2015). African Peacekeepers in Africa: The Role of United States Assistance and Training. African Security Review, 24(1), 23-38. [2]. https://doi.org/10.1080/10246029.2014.993668 
This article was downloaded by: [62.66.130.15]

On: 29 J anuary 2015, At: 01:13

Publisher: Routledge

Informa Ltd Registered in England and Wales Registered Number: 1072954 Registered

office: Mortimer House, 37-41 Mortimer Street, London W1T 3J H, UK

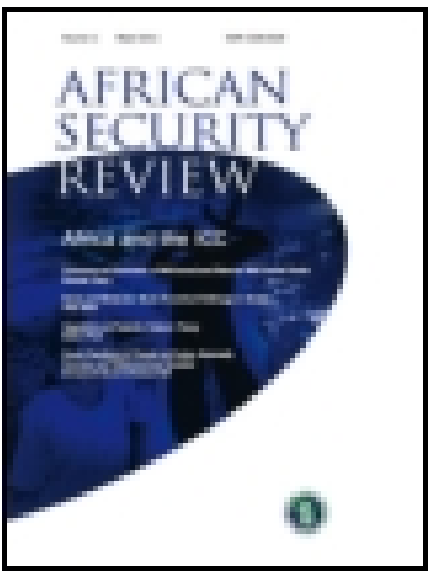

\section{African Security Review}

Publication details, including instructions for authors and subscription information:

http:// www.tandfonline.com/loi/ rasr20

\section{African peacekeepers in Africa}

Nikolas Emmanuel

Published online: 26 J an 2015.

\section{CrossMark}

Click for updates

To cite this article: Nikolas Emmanuel (2015): African peacekeepers in Africa, African Security Review, DOI: $10.1080 / 10246029.2014 .993668$

To link to this article: http:// dx.doi.org/ 10.1080/10246029.2014.993668

\section{PLEASE SCROLL DOWN FOR ARTICLE}

Taylor \& Francis makes every effort to ensure the accuracy of all the information (the "Content") contained in the publications on our platform. However, Taylor \& Francis, our agents, and our licensors make no representations or warranties whatsoever as to the accuracy, completeness, or suitability for any purpose of the Content. Any opinions and views expressed in this publication are the opinions and views of the authors, and are not the views of or endorsed by Taylor \& Francis. The accuracy of the Content should not be relied upon and should be independently verified with primary sources of information. Taylor and Francis shall not be liable for any losses, actions, claims, proceedings, demands, costs, expenses, damages, and other liabilities whatsoever or howsoever caused arising directly or indirectly in connection with, in relation to or arising out of the use of the Content.

This article may be used for research, teaching, and private study purposes. Any substantial or systematic reproduction, redistribution, reselling, loan, sub-licensing, systematic supply, or distribution in any form to anyone is expressly forbidden. Terms $\&$ Conditions of access and use can be found at http://www.tandfonline.com/page/terms-and-conditions 


\section{African peacekeepers in Africa The role of United States assistance and training}

\section{Nikolas Emmanuel}

African states today are strongly encouraged by the United States (US) and other members of the international community to play a more central role in confronting crises on the continent. Indeed, in recent years African armed forces have increasingly served as the backbone supporting various peacekeeping operations in the region. It is important to add that the international community has frequently tried to facilitate the deployment of African armed forces with aid and training. From this reality, the following study goes beyond the current literature by focusing on the international factors behind African participation in United Nations (UN) peacekeeping operations in Africa. In doing so, this research focuses on US military aid and foreign troop training from 2002 to 2012, and its impact on African deployments into UN peacekeeping missions in Africa. As can be expected, such third-party help appears to be an important motivating factor encouraging African troop deployment into crises on the continent.

Keywords Africa, peacekeeping, conflict management, military training, donor assistance, United States, United Nations

\section{Introduction}

Africa is currently experiencing some of the world's deadliest civil conflicts, testing the international community's ability to respond. Nine of the total $16(56 \%)$ United Nations (UN) peacekeeping operations underway are in Africa: Abyei, Central African Republic (CAR), Cote d'Ivoire, Darfur, Democratic Republic of the Congo (DRC), Liberia, Mali, South Sudan and the Western Sahara. While different deployment configurations and mission mandates have been used (including UN, regional and sub-regional peacekeeping, hybrid missions between various levels, and missions led by major international powers), no simple solution has been found. Yet it is apparent that 'since the end of the Cold War, Sub-Saharan 
African states have dramatically increased their participation in international peacekeeping operations in Africa'. ${ }^{1}$ This increased deployment of African peacekeepers to missions in Africa merits further attention.

There are important drawbacks to relying on African peacekeeping forces. Centrally, most African states require outside assistance to prepare and send their armed forces, as well as to maintain them, in missions on the continent. This does not mean that African troops are incapable of being the central actors in peacekeeping operations. Indeed, in recent years some African states have regularly deployed their armed forces into African crises, and in relatively large numbers. However, for the most part, they accomplish this with outside help and incentives, primarily coming in the form of training and assistance. The international donor community, especially the United States (US) - the key donor examined in this study ${ }^{2}$ regularly train and assist African troops in an effort to build up individual state capacities and encourage regional cooperation. ${ }^{3}$ Such training and aid can be critical to helping African states commit their troops to peacekeeping on the continent. As Gompert clearly argues, '[w]ith Western help, capable African combat troops ... can be improved and melded into effective multilateral intervention forces'. ${ }^{4}$

This research asks one critical question. In Africa, how has US military aid and training influenced which countries provide peacekeepers and in what quantities? This study confronts the recent literature on peacekeeping and questions its overemphasis on the domestic characteristics of the troop-sending countries in addressing who commits peacekeepers. In addition to national-level factors, it is important to bring in the role of outside third parties mainly those who supply military training and assistance. This research argues that such aid and training not only prepares African armed forces for peacekeeping, but also acts as enticements or incentives to encourage regional states to deploy peacekeepers into African crises.

This study addresses the above-mentioned research question in three phases. First, it is important to assess the various reasons that motivate African states to provide peacekeepers for the various crises on the continent. This initial section outlines the various arguments behind the desire to encourage African states to be at the forefront of peacekeeping on the continent. Building on this, the second section traces the recent evolution of peacekeeping operations in Africa, while examining the emergence of the key troop-contributing African states in recent years. Finally, this study concludes with a statistical analysis used to capture generalisations about the impact of US-provided aid and training, while controlling for a number of domestic-level variables from the literature on African state actors in their decisions to send troops into UN peacekeeping operations on the continent. The overall objective of this study is to provide an empirical assessment of the impact of US military training and assistance on the deployment of African peacekeepers into regional crises. This analysis points to the conclusion that the US exerts an important influence on who participates in UN peacekeeping missions in Africa and to what extent.

\section{Deploying African troops in Africa}

It is not new to argue that African states should be at the forefront of deploying their own troops as peacekeepers in African crises. ${ }^{5}$ Three main reasons stand out supporting this argument. To begin with, Africans are closest in proximity to the crises on the continent; and 
Africans understand the impact of these conflicts better than any outside force because they experience direct spillover from them. Furthermore, encouraging African deployments within an international, regional or sub-regional multilateral framework builds collective security arrangements, creating closer ties between African states, hopefully facilitating more peaceful interactions. Finally, enabling African states to be more proficient peacekeepers will hopefully enhance state capacities to deal with future crises more effectively.

\section{African proximity to Africa}

First and foremost, proximity stands out as a clear reason for donors such as the US to want to encourage increased African involvement in peacekeeping on the continent. It can be argued that local actors know their neighbours best, much better than any peacekeeping operation comprised of distant outsiders. They have a crucial advantage in that they often have a direct knowledge of the cultures that they are dealing with and the prevailing norms and languages, as well as acceptable and unacceptable behaviours. This closeness 'provides them with a better understanding of a conflict's dynamics, key players and context-specific management and resolution options'. ${ }^{6}$ As a result, regional and sub-regional forces may be better received and accepted by the local populations.

Proximity should also facilitate a much more rapid and less expensive response. Troops from neighbouring countries, along with their equipment, do not need to be ferried across the planet. This advantage should lower logistical and operational costs considerably. Furthermore, it makes sense that the leaders of states in the immediate vicinity of a civil conflict would view ending violence and restoring a functioning state as part of their direct national interest. Extra-regional actors are not as directly impacted by the externalities of such civil wars that are outside of their own neighbourhood.

However, geographical and cultural proximities might not always contribute positively to an intervention and legitimise an intervener's behaviour. Just because you are in the neighbourhood does not mean that you will help out in a benevolent manner. In fact, being from the neighbourhood can be a significant drawback, as the initial problems may directly involve the intervening neighbour. Sub-regional forces can at times make a bad situation worse. There are several clear examples in recent history. Ethiopia's unilateral military incursion into Somalia, which began in 2006 to depose the Union of Islamic Courts, demonstrates that even actors with relatively large armed forces and international (US) support can get bogged down by legitimacy problems. Chad's recent troubled intervention in the CAR provides an additional illustration of how neighbours can exacerbate an already dangerous situation and can be perceived as biased interlopers. A further example is Rwanda, a very strong, emerging military actor on the continent. Over the past decade, Kigali has regularly contributed large numbers of its armed forces as peacekeepers to multilateral peacekeeping operations in Africa. Rwanda has been a critical linchpin in the current joint operation between the African Union (AU) and the UN in Darfur. However, President Paul Kagame's armed forces have also served to undermine stability in central Africa by consistently arming and intervening on behalf of various militia groups in the neighbouring DRC. As Beswick points out, while Rwanda is contributing to 'African solutions' in Darfur, they are also significantly adding to 'African problems' in the DRC. ${ }^{7}$ This only underlines the problems of legitimacy and impartiality that neighbouring states can run into when intervening militarily in their own sub-region. 


\section{Increased role of African states in the international system}

Additionally, participation in conflict management efforts on the continent can improve diplomatic relations between countries and with the international community as a whole. Fundamentally, peacekeeping may augment national prestige on the world stage and increase the participating state's leverage with regard to donors. Shimizu and Sandler suggest that states may benefit from prestige and the enhancement of their overall status when assisting stability efforts in neighbouring countries in crisis. ${ }^{8}$ Participation in south and central Somalia gives the intervening states such as Uganda and Kenya leverage and makes them pivotal players in constructing sub-regional and regional collective security arrangements. Furthermore, these troop-contributing states appear to be upright international citizens, providing a critical public good: peace. Peacekeeping also gives the contributing countries a greater voice than they would otherwise have. It increases their clout in decision-making structures in international bodies such as the UN, the AU and the various sub-regional organisations on the continent.

\section{Strengthening African states}

Donor assistance and training helps strengthen state responses to various crises. This makes it clear why donors and recipients alike desire to enhance African capacities. However, by far the most obvious drawback surrounding the use of African troops in peacekeeping on the continent or anywhere else is that African states lack resources. Most states in the region (besides a very small number) simply cannot fund and undertake their own military interventions without some sort of outside help. Because of various financial, logistical and operational constraints, militaries in the region lack the capacity and the resources to commit meaningfully to conflict prevention and resolution through military means without significant assistance. ${ }^{9}$ This reality is problematic. Unfortunately, '[w]e have ended up with a system where the weakest groups go to the hardest places'. ${ }^{10}$ This significantly undermines the autonomy of African states when it comes to mounting peacekeeping operations.

To build capacities, donors have increased their provision of military assistance and troop training to Africa in recent years. Figure 1, containing data on US foreign military training levels, provides evidence of this trend.

Interestingly, US military training of African soldiers has seen a marked increase since 2007. With this, the US is trying to encourage and support African deployment of peacekeepers into peacekeeping operations in the region. The Bureau of African Affairs

\section{Figure 1 Total annual number of African troops trained by the US}

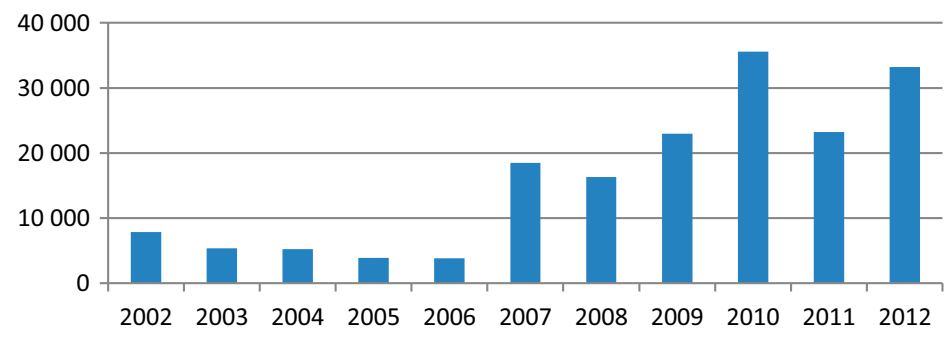

Source US Department of State, Foreign military training and Department of Defense (DoD) engagement activities of interest, www.state.gov/t/pm/rls/rpt/fmtrpt/ 
within the US Department of State funds and manages Africa Contingency Operations Training and Assistance (ACOTA) as part of the Global Peace Operations Initiative (GPOI). The US Department of Defense (DoD) and private contractors support this programme, designed to prepare African armed forces for peacekeeping. Between 1997 and 2012, ACOTA (and its predecessor the African Crisis Response Initiative, ACRI) trained 215000 soldiers, while facilitating the deployment of approximately 20 African battalions annually. ${ }^{11}$ These types of training programmes aim to build the capacities of the armed forces of African states while encouraging their participation in peacekeeping operations on the continent.

\section{Encouraging African peacekeeping in Africa}

Turning to Africans to deal with crises and civil conflicts in the region is nothing new. Just as the Berlin Wall fell, one began to see the emergence of an embryonic sub-regional security complex in West Africa. The Nigerian-led Economic Community of West African States Monitoring Group (ECOMOG) intervention into the Liberian civil war in August 1990 characterises these developments. Such a move represented an important turning point in the construction of an African crisis response infrastructure on the continent. Since then, African participation in most multilateral military interventions in Africa has been high. These actions have frequently been under African command and within the framework of (or in cooperation with) an African regional or sub-regional organisation.

At the time of the Liberian intervention, former UN Secretary-General Boutros BoutrosGhali in An Agenda for Peace argued that regional security arrangements are an important part of peacekeeping in order to help relieve the UN's increasingly heavy peacekeeping burden in the wake of the end of the Cold War. ${ }^{12}$ Three years later, after the botched Somalia intervention and the lack of action during the Rwandan genocide, Boutros-Ghali also wrote in a report entitled Improving Preparedness for Conflict Prevention and Peace-keeping in Africa that there was an important role for regional organisations in the activities of the UN on the continent:

It is increasingly apparent that the United Nations cannot address every potential and actual conflict troubling the world. Regional or sub-regional organizations sometimes have a comparative advantage in taking the lead role in the prevention and settlement of conflicts and to assist the United Nations in containing them. ${ }^{13}$

Today, a number of African states actively participate in peacekeeping operations in the region. As discussed earlier, African governments are acutely aware of the desire for them to send troops to help in peacekeeping operations in Africa. This may be because, as Donald Rothchild has indicated, African states are 'increasingly viewing some type of self-help as essential to reduce threats from violence' and the spillover of externalities from neighbouring conflicts. ${ }^{14}$ This self-help or 'neighbourhood watch' conflict management method has become critical in confronting state crises across Africa. Furthermore, Adebajo adds that, 'like a sheriff, [African states] must demonstrate capacity and political will to gather a posse in defence of mutual regional security interests'. ${ }^{15}$ For these reasons, among others, states in the region are willing to contribute troops and to help manage conflict in their backyard. Yet, which African states have been deploying their troops in crises on the continent? Table 1 gives the annual average for the peacekeeping troops deployed by African states in multilateral UN operations between 2002 and 2012. 


\section{Table 1 Top 10: annual average number of African troops deployed in UN peacekeeping operations in Africa (2002-2012) ${ }^{16}$}

\section{Country}

Nigeria

Ethiopia

Ghana

Egypt

Rwanda

South Africa

Morocco

Senegal

Kenya

Benin

\begin{tabular}{|r|} 
Annual average number of troops deployed in Africa (2002-2012) \\
\hline 3591 \\
\hline 2996 \\
1869 \\
1813 \\
1691 \\
1627 \\
1418 \\
1196 \\
1182 \\
\hline 747
\end{tabular}

Source UN, Troop and police contributors archive (1990-2013), www.un.org/en/peacekeeping/resources/statistics/contributors_archive.shtm/

These states are frequently the most willing to commit troops to conflict management efforts on the continent. As Alex Bellamy and Paul Williams note, they make up the small core of African states that do most of the African peacekeeping. ${ }^{17}$ These critical actors are central in the development of regional security complexes capable of tackling state crises on the continent. ${ }^{18}$ As Deng et al. point out, '[r]egions generally are organized around certain states that have the power and position potentially to play the role of hegemon or act as a pole around which the security or insecurity of other states revolves'. ${ }^{19}$ The 10 states in Table 1 are such hegemonic states.

\section{Empirical analysis}

While much of the research on who contributes peacekeepers focuses on the domestic factors of the sending state, the research presented here brings in two international factors: the role of external third-party military aid and foreign troop training. Given the capacity gap of a number of African states, international donors can play a critical role in enabling African troops to participate in peacekeeping operations. This study examines 54 states in Africa during the period from 2002 to 2012, the unit of analysis being the country-year. This should provide 594 country-year observations. However, due to missing data, the overall number of country-years available for analysis is somewhat less (see Table 3). This problem is due to the fact that in some cases such as Somalia and the DRC, data simply does not exist in any accurate form on a number of variables during some years for the period in question. Such longitudinal data (in cross-sectional and time-series form) requires the use of particular statistical techniques that can take into consideration relationships measured across time and space. Before moving on to the statistical analysis, however, it is pertinent to discuss the key variables operationalised in this study.

The dependent variable used here provides a count of the total annual amount of a given country's troops that are sent to participate in UN peacekeeping operations in Africa. ${ }^{20} \mathrm{Put}$ differently, each country-year observation on the dependent variable consists of the total 
number of peacekeepers that the particular country sends into UN peacekeeping operations in Africa for each particular year. For example, Zambia provided 352 troops for UN peacekeeping in African in 2012 and Nigeria sent 3159 troops in 2002, while Ethiopia deployed 6116 peacekeepers to UN peacekeeping operations in 2011. The average annual deployment of African troops in UN peacekeeping operations in Africa between 2002 and 2012 consisted of approximately 362 troops per country, per year. The information for the dependent variable is derived from online documents maintained by the UN's Department of Peacekeeping Operations (UNDPKO). For consistency, year-end, December data has been used to construct the dependent variable, providing a cross-sectional time-series in which a generalised least square (GLS) method is used to compensate for temporal and spatial dependence between groups of observations in the dataset. The statistical package STATA has been used for undertaking the quantitative analyses.

The literature concerning peacekeeping deployments focuses primarily on the domestic characteristics of the sender nation. To measure these national-level factors, three explanatory variables are operationalised, measured with readily available annual data: gross national income (GNI) per capita; Freedom House political rights and civil liberties scores; and the total number of military personnel in a given country. However, the research presented here brings in two international factors: US military aid and US troop training. These influences should have a positive impact and encourage the deployment of peacekeepers.

\section{Independent variables based on domestic factors}

\section{GNI per capita, Atlas method (current US\$)}

An important argument in the literature points out that relatively poorer countries in Africa should deploy their troops more readily into regional and sub-regional peacekeeping operations on the continent, as opposed to richer ones. ${ }^{21}$ Victor along with Bove and Elia find that a country's troop contributions to peacekeeping operations are best explained by its relative wealth or, more specifically, the lack of relative wealth. ${ }^{22}$ That is to say, the poorer a country is, the more likely it is to participate in peacekeeping because poorer countries would benefit most from foreign donations of soldier stipends, training and military equipment. A big motivating factor is that supplemental pay for troops participating in UN operations stands at around US $\$ 1000$ per month. ${ }^{23}$ This is a windfall for many soldiers from African countries. Furthermore, the troop-contributing states can take their own cut of this dividend in the form of taxes. As a baseline control variable, the World Bank's World Development Indicators (WDI) annual data for per capita income are used. ${ }^{24}$ From this, it seems easy to advance the hypothesis that there should be a negative correlation between higher than average GNI per capita and the deployment of peacekeepers. That is to say, the richer a country is, the less likely it would be to committing its troops to peacekeeping operations.

\section{Freedom House democracy scores}

The peacekeeping literature also frequently uses the troop contributor's level of democracy as an indicator to determine which states will participate in peacekeeping operations. Anderson argues that democratic states commonly step forward to defend international stability and assist populations in dire need. ${ }^{25}$ Lebovic along with Daniel and Caraher conclude that democracies are much more likely to deploy their armed forces in peace operations. ${ }^{26}$ To capture this purported relationship, Freedom House scores are used in this study. ${ }^{27}$ The 
measurement for Political Rights to the Civil Liberties score is added, and the result divided by two, providing a one- to seven-point scale. In this aggregate of the two Freedom House democracy scores, a seven indicates a highly authoritarian country. A score of one denotes a highly democratic state. Based on the literature, one should expect that democratic governance should be present in the most consistent peacekeeping states. That is to say, there should be a negative relationship between the Freedom House scores and the number of troops deployed (i.e., peacekeeping operation participants should have a lower number on these democracy scores, thus indicating that they are relatively more democratic).

\section{Total armed forces personnel}

There is not an equal distribution of military power among the nations of Africa. ${ }^{28}$ From this, it seems obvious to argue that countries with large armed forces should be able to send more of their troops to peacekeeping operations. According to Khanna, Sandler and Shimizu, and Shimizu and Sandler, relatively stronger states, with larger than average militaries, can and should contribute disproportionately to peacekeeping. ${ }^{29}$ Victor also finds that the size of a state's military successfully predicts their contribution to UN peacekeeping. ${ }^{30}$ The size of a given African state's military should have a positive impact on their willingness to send troops into multilateral peacekeeping operations on the continent. This explanatory variable is derived from the World Bank's World Development Indicators for this study. ${ }^{31}$

\section{Independent variables based on external factors (assistance and training)}

Beyond the domestic factors frequently brought up in the peacekeeping contributions literature, it is argued that states can be encouraged to send their troops on peacekeeping operations through the provision of aid and training from the international community. This research examines data from the principle donor of military aid and training to African states the US. This particular donor is used because of the availability of data on its activities. The variables for US military assistance and US military training are lagged by one year on the data from the dependent variable, meaning that, for example, the choice to deploy peacekeepers in a given year is influenced by the aid and training from the previous year. Therefore, aid and training impacts future troop contributions.

\section{US military assistance}

Pushing the peacekeeping responsibilities onto African states means that there must be an increased emphasis on building up their military capacities. ${ }^{32}$ Helping along these lines is also important for encouraging participation in peacekeeping operations. Since most African states require some assistance in sending their armed forces abroad and maintaining them in the theatre, it is critical to examine how African governments react to the provision of donor military aid. It makes sense to argue that troop-contributing countries in Africa would decide to deploy peacekeepers in the region in exchange for foreign military aid. This training and equipment should strengthen and modernise their security forces. This study advances the hypothesis that military aid should correlate positively with African peacekeeping troop deployments. That is to say, larger than average amounts of military assistance should incite African state recipients to send more troops into hot spots on the continent as peacekeepers. In order to measure this, US military assistance as a proxy is used, since this funding information 
is readily available from the US Agency for International Development (USAID). ${ }^{33}$ The US military aid data is lagged by one year behind the dependent variable.

\section{US military training}

As discussed throughout this study, the international community has increasingly tried to bolster the response capacity of African militaries and encourage their deployment as peacekeepers on the continent. To encourage deployment, the US provides foreign assistance along with troop training for their armed forces. Washington's ACOTA and GPOI programmes train African armed forces with the direct objective of encouraging and facilitating their deployment into peacekeeping operations on the continent. However, do African states respond to military training by sending their armed forces to participate in peacekeeping? Again, because of the availability of data, only troop training provided by the US is used. ${ }^{34}$ The US is the principle trainer of African armed forces, preparing them for deployment in peacekeeping operations on the continent and elsewhere. It is argued that military education programmes from the US should be excellent predictors of future deployments. The ability to participate in such military training programmes represents an important incentive and potential to build capacity, undertaken in exchange for African states sending their troops into multilateral peace operations on the continent. This explanatory factor is lagged by one year on the dependent variable, as training from the previous year should have a positive impact and encourage peacekeeping troop deployments in the given observed year on the outcome variable.

\section{Discussion of statistical results}

This study examines several factors that influence the deployment of peacekeeping forces sent by African states into peacekeeping operations on the continent. Table 2 on next page top provides a starting point with some interesting descriptive statistics on the profiles of the top 10 African contributors to UN peacekeeping operations.

Out of the 10 states listed in the table above, one state in particular stands out - so much so that it should have an impact on any statistical analysis. Egypt clearly is something of an outlier in terms of the US military aid it receives and the overall size of its armed forces. Cairo's army is a leviathan with 835500 active armed forces personnel (in 2012), by far the largest military force in Africa. ${ }^{35}$ Furthermore, Washington sends a colossal amount of foreign military assistance to Egypt, with just over US $\$ 1,3$ billion in 2012 (averaging around US $\$ 1,5$ billion annually between 2002 and 2012). This is considerably more than the entire annual bilateral US military aid budget for the rest of Africa, which totalled only US $\$ 293$ million in 2012 . Since Egypt is such a significant outlier, it skews the results of any quantitative analysis. To remedy this problem, it is necessary to run separate statistical models, both with and without the case of Egypt in the dataset.

Beyond Egypt as an outlier, there is an additional significant problem. It appears that high levels of intercorrelation exist between several of the independent variables. This alters the statistical results in rather important ways. Primarily, two of the explanatory variables correlate at relatively high levels with the factor controlling for overall military size. The largest correlation is between military size and US military assistance at the level of 0,843 . In addition, military size and Freedom House scores also intercorrelate at a relatively high level of 0,299. The relationships between these independent variables make it necessary to run statistical 
Table 2 Top 10: profiles of key African peacekeepers ${ }^{36}$

\begin{tabular}{|c|c|c|c|c|c|}
\hline Country & $\begin{array}{l}\text { Average annual } \\
\text { UN } \\
\text { peacekeepers } \\
\text { deployed in } \\
\text { Africa }\end{array}$ & $\begin{array}{l}\text { Average } \\
\text { annual } \\
\text { troops } \\
\text { trained } \\
\text { by US }\end{array}$ & $\begin{array}{l}\text { Average annual } \\
\text { US military aid } \\
\text { (US\$) }\end{array}$ & $\begin{array}{l}\text { Overall } \\
\text { size of } \\
\text { armed } \\
\text { forces } \\
(2012)\end{array}$ & $\begin{array}{l}\text { Freedom } \\
\text { House } \\
\text { scores } \\
\text { (2012) }\end{array}$ \\
\hline Nigeria & 3591 & 2021 & 4979720 & 162000 & 4 \\
\hline Ethiopia & 2996 & 313 & 2867545 & 138000 & 6 \\
\hline Ghana & 1869 & 1442 & 2168040 & 15500 & 1,5 \\
\hline Egypt & 1813 & 1086 & 1477582741 & 835500 & 5,5 \\
\hline Rwanda & 1691 & 980 & 1164388 & 35000 & 5,5 \\
\hline South Africa & 1627 & 392 & 2691726 & 77153 & 2 \\
\hline Morocco & 1418 & 245 & 19595331 & 245800 & 4,5 \\
\hline Senegal & 1196 & 1087 & 3097389 & 18620 & 3 \\
\hline Kenya & 1182 & 357 & 5362199 & 29120 & 3,5 \\
\hline Benin & 747 & 847 & 358981 & 9450 & 2 \\
\hline $\begin{array}{l}\text { African } \\
\text { average }\end{array}$ & 389 & 301 & 32303851 & 63628 & 4,4 \\
\hline
\end{tabular}

models with and without the annual military size variable in the analysis. This should allow for more accurate statistical results, and a better understanding of the relationship between the explanatory variables and the deployment of UN peacekeepers in Africa. Overall, in order to deal with the outlier and intercorrelation problems, it is necessary to run four separate models in the statistical analysis.

Because the dataset is longitudinal, a GLS regression is used to analyse the data in this study. ${ }^{37}$ This technique can take cross-sectional data and time into consideration. A straightforward ordinary least squares (OLS) regression or even a logistical regression would not be able to take data grouped by time and space into consideration. It is a key assumption of OLS or logistic regressions techniques that observations cannot relate with other observations. However, the data groups on country and time, violating this assumption - thus, use of a GLS analysis is necessary. Table 3 presents the results for the four regression analyses.

In the results from the statistical analysis, presented in Table 3 on next page, several interesting findings stand out and require further discussion. To begin with, the direction of the coefficient concerning the variable for per capita income (GNI per capita) is negative across all four models. This is consistent with the hypotheses put forward in this study and with the arguments most frequently found in the relevant literature on peacekeeping troop contributions. That is to say, although this independent variable is not statistically significant, one should expect that during the period in question, poorer (lower GNI per capita) African states should more readily participate in peacekeeping operations on the African continent. At least three explanations are clear: the pull factor of wages received by troops deployed in peacekeeping operations; the desire of poorer states to build the capacities of their armed forces; and the need to strengthen sub-regional security structures and combat the spillover effects of conflicts in neighbouring states. However, it is important to point out that these results are not statistically significant. 
Table 3 GLS regression analyses ${ }^{38}$

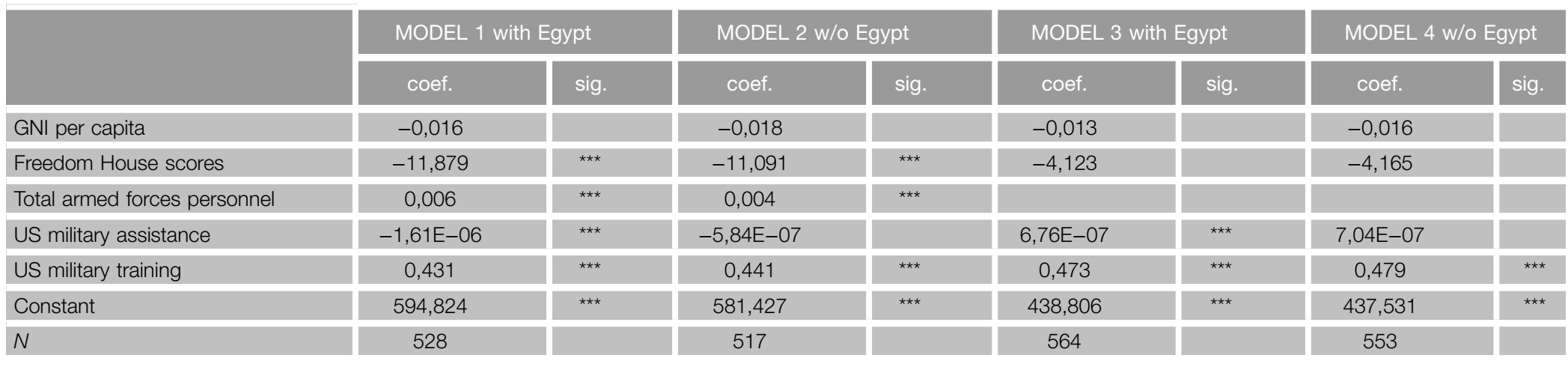

Notes ${ }^{* *}=$ highly statistically significant at $<0.001$ 
Perhaps more interesting, in Model 1, four out of the five independent variables operationalised in this study (Freedom House scores, armed forces size, US military training and US military assistance) are highly statistically significant, with two having a positive impact on the dependent variable while the other two relationships in the data are negative. Different configurations of the cases (including the outlier Egypt or not) and of the operationalised explanatory factors (including or excluding the variable for overall military size) lead to somewhat different results. However, the exception is the variable for US troop training that remains positive and highly statistically significant across all of the models. These results deserve further elaboration.

First, from the statistical results in this study, countries with high Freedom House scores (consisting of the average of the given country's annual political rights and civil liberties scores) are less likely to send members of their armed forces as peacekeepers in UN operations across Africa. Since higher scores on these Freedom House indicators point to more authoritarian forms of governance, the negative result produced here leads to the belief that democracies more readily deployed peacekeepers in these African cases during the period in question. The literature also frequently evokes this relationship. Simply put, the more democratic states in Africa appear to send a larger number of troops to join UN peacekeeping operations in Africa than the authoritarian states on the continent. From the descriptive statistics in Table 2, six of the top 10 troop-contributing states (Benin, Ghana, Kenya, Nigeria, Senegal and South Africa) all have Freedom House scores (2012) below the overall African average of 4,4. Yet, this does not stop relatively authoritarian states such as Ethiopia, Rwanda or Egypt from sending a significant number of troops into peacekeeping operations on the continent. Problematically, it is important to note that this variable correlates highly with the total number of armed forces from a given country. When excluding military size from the regression analysis, Freedom House scores are no longer significant, although the relationship remains negative.

Furthermore, the independent variable for the overall annual size of a given country's armed forces appears to be highly significant and have a positive relationship with the number of peacekeeping troops deployed, when controlling for other factors. This positive relationship echoes throughout the recent literature, as discussed in a previous section. While the inclusion of this factor was limited to only two of the four models in the regression analysis due to intercorrelation with two other important explanatory variables, the results do suggest that African countries with large armed forces are more likely to deploy their troops as UN peacekeepers on the continent. Five out of the top 10 UN peacekeeping troop contributors (Egypt, Ethiopia, Morocco, Nigeria and South Africa) are all above the African average in their total armed forces personnel, which is 63628 for the entire continent. ${ }^{39}$ However, it is important to add that Egypt is a clear outlier, with 835500 troops (in 2012), far larger than any other military in Africa. Regardless, this does not stop countries with relatively small armed forces, such as Benin or Ghana, from regularly sending their troops to support UN missions.

More importantly for this research, the two variables that examine the impact of external actors in the deployment of African troops into UN peacekeeping operations in the region appear to provide some interesting results that clearly require future attention. The two issues of intercorrelation, and the outlier of Egypt, provide problems for understanding the influence of US military assistance on African peacekeeping. Due to the very high levels of correlation between armed forces size and the explanatory variable for US military assistance, when used together in any regression analysis these two factors influence and skew each other's results. 
Therefore, out of the four GLS regression models proposed in Table 3, Model 4 seems to capture the impact of US military assistance the best. Without Egypt or the military size variable altering the statistical results, it appears that US military assistance has a positive relationship with African peacekeeping troop deployment in Africa. However, this statistical correlation is not significant in Model 4. Although this empirical relationship is weak, it does point in the direction that military aid from Washington may be encouraging African states to deploy members of their armed forces peacekeepers. However, when examining the empirical data further, in a more descriptive manner, as in Table 4 below, some interesting trends stand out.

Again, it is critical to note the presence of a huge outlier, Egypt. Cairo received an average of close to US $\$ 1,5$ billion in military assistance annually from the US between 2002 and 2012. This dwarfs the other top 10 US military aid recipients. In addition, four of the 10 countries in Table 4 (DRC, Liberia, Somalia and Sudan/South Sudan) are either emerging from civil wars, or are still engaged in them. Donors like the US send military assistance to these states not necessarily to encourage them to send their troops abroad as peacekeepers, but to help them fight insurgents at home. In addition, it is worth pointing out that eight out of the 10 (Djibouti, Egypt, Kenya, Morocco, Nigeria, Somalia, Sudan/South Sudan and Tunisia) are involved, in one way or another, in the US global war on terrorism. This military aid is perhaps not to facilitate or pay for peacekeeping but used instead to help the US pursue its fight against terrorism. These explanations help us to understand why US military aid does not correlate with levels of African peacekeeping in any statistically significant manner.

However, the most important finding in this research is that US foreign military training correlates with the amount of African troops deployed into UN peacekeeping operations in Africa. This correlation is positive and highly statistically significant. Unlike the other indicators, Egypt is not an outlier in US troop training. In addition, the other explanatory variables do not have high levels of intercorrelation with military training. This explains why the direction of the relationship between troop training and the dependent variable remains positive and statistically significant across the four models, as seen in Table 3 . These empirical results indicate that the US military training of African troops at year $t-1$ as part of programmes such as ACOTA strongly correlate with the deployment of that same country's

Table 4 Average annual US military assistance (2002-2012)

\begin{tabular}{|l|c|}
\hline & Average annual US military assistance (US\$) \\
\hline Egypt & 1477582740 \\
\hline Sudan & 98730133 \\
\hline Somalia & 47655450 \\
\hline Liberia & 27415875 \\
\hline Morocco & 19595331 \\
\hline Tunisia & 13666432 \\
\hline DRC & 8537892 \\
\hline Kenya & 5362198 \\
\hline Djibouti & 5080396 \\
\hline Nigeria & 4979719 \\
\hline
\end{tabular}

Source USAID, U.S. overseas loans and grants, obligations and loan authorizations, https://eads.usaid.gov/gbk/data/greenbook.cfm 
troops as part of a UN peacekeeping operation on the continent at time $t$. That is to say, the previous year's US training has an extremely strong, positive influence on the next year's decision to send troops to support a UN peacekeeping operation on the continent. Troop training appears to not only be crucial in developing the capacity of various armed forces in Africa, but US military training programmes such as ACOTA and GPOI are actually providing important incentives that facilitate and encourage the deployment of African armed forces on the continent as peacekeepers. Encouraging African peacekeeping in Africa is one of the stated goals of ACOTA, and it appears to be working.

\section{Conclusion}

As Paul Williams indicates, 'African governments bear the primary responsibility' for dealing with and responding to the various conflicts on the continent today. ${ }^{40}$ It makes sense to increase African participation in activities such as peacekeeping on the continent. This builds a sense of ownership and responsibility, while encouraging African states to cooperate in building regional and sub-regional conflict management structures. That said, it is important to understand what motivates critical actors in Africa to participate in the construction of various security infrastructures on the continent, beyond simple ad hoc responses to given conflicts. If the US or other actors in the international community want to get help from Africa to deal with problems in the region, they should clearly be building state capacities and encouraging states in the region to cooperate so that they can play a larger role together. As this study argues, US training programmes appear to play an important role in this process. The relationship between the incentives provided by the key actors in international community and the willingness of African states to deploy their own peacekeepers into costly and dangerous situations must be examined further by both expanding the number of donors and recipients, as well as the types of incentives. This is important since, as demonstrated here, aid and training can be highly motivating forces.

\section{Notes}

$1 \mathrm{~J}$ Victor, African peacekeeping in Africa: warlord politics, defense economics, and state legitimacy, Journal of Peace Research, 47, 2010, 217.

2 It is important to add that due to data availability, this study examines military training and assistance provided by the US. While there are drawbacks from limiting the research to only one donor, the US is the primary provider of military aid and troop training to Africa, so this, nonetheless, provides an excellent picture of the way donors shape African peacekeeping on the continent today.

3 D Beswick, Peacekeeping, regime security and 'African solutions to African problems': exploring motivations for Rwanda's involvement in Darfur, Third World Quarterly, 31, 2010.

4 D Gompert, For a capability to protect: mass killing, the African Union and NATO, Survival, 48, $2006,10$.

5 G Evans, Cooperating for peace, Canberra: Allen and Unwin, 1994.

$6 \mathrm{~K}$ Powell, The African Union's emerging peace and security regime - opportunities and challenges for delivering on the responsibility to protect, Pretoria: Institute for Security Studies (ISS), 2005, 20.

7 D Beswick, Peacekeeping, regime security and 'African solutions to African problems': exploring motivations for Rwanda's involvement in Darfur, Third World Quarterly, 31, 2010, 751.

8 H Shimizu and T Sandler, Peacekeeping and burden-sharing, 1994-2000, Journal of Peace Research, 39, $2002,656$.

9 M Juma and A Mengistu, The infrastructure of peace in Africa: assessing the peacebuilding capacity of African institutions, New York, NY: International Peace Academy, 2002. 
10 E Dickinson, For tiny Burundi, big returns in sending peacekeepers to Somalia, Christian Science Monitor, 22 December 2011, www.csmonitor.com/World/Africa/2011/1222/For-tiny-Burundi-big-returns-in-sendingpeacekeepers-to-Somalia.

11 US Africa Command, Fact sheet: ACOTA, October 2012, www.africom.mil/Doc/9836.

12 B Boutros-Ghali, An agenda for peace: preventive diplomacy, peace making and peacekeeping, SI A/47/277-S/24111, 17 June 1992, New York, NY: UN, paragraph 64.

13 B Boutros-Ghali, Improving preparedness for conflict prevention and peacekeeping in Africa: Report of the Secretary-General, SI A/50/711 and S/1995/911, 1 November 1995, New York, NY: UN, paragraph 4.

14 D Rothchild, The effects of state crisis on African interstate relations (and comparisons with post-Soviet Eurasia), in M Bessinger and C Young (eds.), Beyond state crisis? Postcolonial Africa and post-Soviet Eurasia in comparative perspective, Washington, DC: Woodrow Wilson Center Press, 2002, 207.

15 A Adebajo and C Landsberg, South Africa and Nigeria as regional hegemons, in M Baregu and C Landsberg (eds.), From Cape to Congo: southern Africa's evolving security challenges, Boulder, CO: Lynne Rienner, $2003,174$.

16 Note that Table 1 only contains contributions to UN peacekeeping operations. Critical actors such as Uganda and Burundi contribute a large amount of troops to the AU mission in Somalia (AMISON), which would put them on this list.

17 A Bellamy and P Williams, Providing peacekeepers: the politics, challenges, and future of United Nations peacekeeping contributions, Oxford: Oxford University Press, 2013.

18 D Lake and P Morgan, Regional orders: building security in a new world, University Park, PA: The Pennsylvania State University Press, 1997, 12. Note that the concept of a regional security complex originates with B Buzan, People, states \& fear: an agenda for international security studies in the post-Cold War era, Boulder, CO: Lynne Reinner, 1991, 190.

19 F Deng et al, Sovereignty as responsibility: conflict management in Africa, Washington, DC: The Brookings Institution, 1996, 133.

20 It would be beneficial to go beyond UN peacekeeping missions and add AU operations along with sub-regional ones. However, the data for the non-UN regional and sub-regional missions in Africa are not readily available and frequently sources contradict each other.

$21 \mathrm{~J}$ Victor, African peacekeeping in Africa: warlord politics, defense economics, and state legitimacy, Journal of Peace Research, 47, 2010, 217.

$22 \mathrm{~J}$ Victor, African peacekeeping in Africa: warlord politics, defense economics, and state legitimacy, Journal of Peace Research, 47, 2010, 217; V Bove and L Elia, Supplying peace: participation in and troop contribution to peacekeeping missions, Journal of Peace Research, 48, 2011.

23 E Dickinson, For tiny Burundi, big returns in sending peacekeepers to Somalia, Christian Science Monitor, 22 December 2011, www.csmonitor.com/World/Africa/2011/1222/For-tiny-Burundi-big-returns-in-sendingpeacekeepers-to-Somalia.

24 World Bank, World Development Indicators 2013, GNI per capita, Atlas method (current US\$), http://data. worldbank.org/indicator/NY.GNP.PCAP.CD (accessed 10 December 2014).

25 A Andersson, Democracies and UN peacekeeping operations, 1990-1996, International Peacekeeping, 7:2, 2000.

26 James Lebovic, Uniting for peace? Democracies and United Nations peace operations after the Cold War, Journal of Conflict Resolution, 48, 2004; D Daniel and L Caraher, Characteristics of troop contributors to peace operations and implications for global capacity, International Peacekeeping, 13, 2006.

27 Freedom House, Freedom in the world 2013, www.freedomhouse.org/report/freedom-world/freedom-world2013\#.Uv0jktGYbIU (accessed 10 December 2014).

28 B Mtimkulu, The African Union and peace support operations, Conflict Trends, 4:1, 2005.

29 J Khanna, T Sandler and H Shimizu, Journal of Conflict Resolution, 42, 1998; H Shimizu and T Sandler, Peacekeeping and burden-sharing, 1994-2000, Journal of Peace Research, 39, 2002.

$30 \mathrm{~J}$ Victor, African peacekeeping in Africa: warlord politics, defense economics, and state legitimacy, Journal of Peace Research, 47, 2010.

31 World Bank, World Development Indicators 2013, Armed forces personnel, total, http://data.worldbank.org/ indicator/MS.MIL.TOTL.P1 (accessed 10 December 2014).

32 D Beswick, Peacekeeping, regime security and 'African solutions to African problems': exploring motivations for Rwanda's involvement in Darfur, Third World Quarterly, 31, 2010.

33 USAID, Greenbook: U.S. overseas loans and grants, obligations and loan authorizations, https://eads.usaid.gov/ gbk/data/greenbook.cfm (accessed 10 December 2014). 
34 US Department of State, Foreign military training and DoD engagement activities of interest, www.state.gov/t/pm/ $\mathrm{rls} / \mathrm{rpt} / \mathrm{fm} t r p t /$ (accessed 10 December 2014).

35 International Institute for Strategic Studies J Hackett (ed.), The military balance 2013, London: Routledge, 2013, https://www.iiss.org/en/publications/military-s-balance.

36 Sources: US Department of State, Foreign military training and DoD engagement activities of interest, www.state. gov/t/pm/rls/rpt/fmtrpt/ (accessed 10 December 2014); UN, Troop and police contributors archive (1990-2013), www.un.org/en/peacekeeping/resources/statistics/contributors_archive.shtml (accessed 10 December 2014); USAID, Greenbook: U.S. overseas loans and grants, obligations and loan authorizations, https://eads.usaid.gov/ gbk/data/greenbook.cfm (accessed 10 December 2014); International Institute for Strategic Studies J Hackett (ed.), The military balance 2013, London: Routledge, 2013, https://www.iiss.org/en/publications/military-s-balance; Freedom House, Freedom in the World 2014, www.freedomhouse.org/report-types/freedom-world\#.VHSO wk10zIU (accessed 10 December 2014).

37 The statistical analysis package STATA and the xtgls command are used in this study.

38 Sources: UN, Troop and police contributors archive (1990-2013), www.un.org/en/peacekeeping/resources/ statistics/contributors_archive.shtml (accessed 10 December 2014); World Bank, World development indicators, http://data.worldbank.org/data-catalog/world-development-indicators (accessed 10 December 2014); Freedom House, Freedom in the World 2014, www.freedomhouse.org/report-types/freedom-world\#.VHSOwk10zIU (accessed 10 December 2014); International Institute for Strategic Studies J Hackett (ed.), The military balance 2013, London: Routledge, 2013, https://www.iiss.org/en/publications/military-s-balance; USAID, Greenbook: U.S. overseas loans and grants, obligations and loan authorizations, https://eads.usaid.gov/gbk/data/greenbook.cfm (accessed 10 December 2014); US Department of State, Foreign military training and DoD engagement activities of interest, www.state.gov/t/pm/rls/rpt/fmtrpt/ (accessed 10 December 2014).

39 UN, Troop and police contributors archive (1990-2013), www.un.org/en/peacekeeping/resources/statistics/ contributors_archive.shtml (accessed 10 December 2014).

40 PD Williams, Keeping the peace in Africa: why 'African' solutions are not enough, Ethics E International Affairs, 22 , 2008,310 . 